\title{
Seed abnormalities and associated mycoflora of rain- fed wheat (Triticum aestivum L.) in South Western Nigeria
}

\author{
O. A. Enikuomehin \\ Department of Crop Protection, University of Agriculture, P. M. B 2240, Abeokuta, Nigeria. \\ E-Mail: adeenikuomehin@yahoo.com.
}

Accepted 14 May, 2005

\begin{abstract}
The health of wheat seeds produced under rain-fed conditions in South Western Nigeria was investigated. There were more abnormal $(1.0-79.7 \%)$ than normal $(10.7-28.7 \%)$ seeds. Forms of seed abnormality observed include wrinkled seeds $(64.2-79.7 \%)$, entirely discoloured seeds $(1.0-12.5 \%)$, seeds with discoloured embryo (germ) $(1.2-1.5 \%)$ and brush $(0.25-1.25 \%)$ ends. Fusarium graminearum and Helminthosporium sativum were associated with all seeds, but at higher levels in abnormal ( $F$. graminearum, $0.5-78.5 \%$; $H$. sativum, $2.5-86.0 \%)$ than normal seeds $(F$. graminearum, $2.25 \% ; H$. sativum, $0.75 \%$ ). Viability of abnormal seeds was $1.50-32.0 \%$ which is much lower than the $88.0 \%$ germination of normal seeds.
\end{abstract}

Key words: Fungi, seed health testing, seed discolouration, wheat.

\section{INTRODUCTION}

Abnormality in seeds is a major constraint in crop production in most developing countries. Seed abnormality due to the influence of seed-borne fungi is very common and often accounts for a large percentage of crop losses (Varshney, 1990). However, a first step towards the attainment of optimal crop yield is the use of high quality seeds (Venter, 2000). Seed abnormality could be in form of shrunken seeds, reduced seed size, seed rot, seed necrosis and partial or total seed discolouration (Shetty, 1993). Invasion of seed by fungi may also result in biochemical deterioration and change in quality of nutrients (Vijaya and Karana, 1981). Discounted prices are paid for abnormal seeds (Varshney, 1990) and such seeds result in poor stands and reduced field emergence values (Tenkouano and Sereme, 1996).

A wide range of mycotoxins are found in seeds infected by fungi (Nanaiah et al., 1986; Tanaka et al., 1990) and these have harmful effects on man and animals that consume such seeds (Williams and Blaney, 1994). The type and severity of seed abnormality may be dependent on the type and pathogenic potential of the associated fungi as well as the prevailing weather conditions (Owolade et al., 2001). Although the range of fungi associated with wheat seed abnormalities have been reported (Prescott et al., 1986; Wiese et al., 1987; Vashney, 1990), there is the need to identify and determine the effects of fungi associated with the abnormality of wheat seeds produced in areas other than the traditional growing areas, as it is with rain-fed wheat cultivation in South-Western Nigeria. This report is a summary of the study.

\section{MATERIALS AND METHODS}

Dry inspection of seeds

$400 \mathrm{~g}$ of seed of four wheat cultivars; Sonalika, Siette ceros, Pavon 76 and Indus 66 were harvested at maturity from rain-fed plots in Ibadan, South-Western Nigeria $\left(7^{\circ} 20^{\prime} \mathrm{N}\right.$; $\left.3^{\circ} 54^{\prime} \mathrm{E}\right)$. Each cultivar was examined by visual inspection under the stereoscopic binocular microscope for normal and abnormal seeds. Normal seeds were those with smooth coat, light brown to butter colour without discolouration or fungal propagules. Abnormal seeds were those 
Table 1. Incidence of normal and abnormal wheat seeds from dry inspection of seeds.

\begin{tabular}{|l|c|c|c|c|c|}
\hline Cultivars & $\begin{array}{c}\text { Normal } \\
\text { seeds (\%) }\end{array}$ & $\begin{array}{c}\text { Wrinkled } \\
\text { seeds (\%) }\end{array}$ & $\begin{array}{c}\text { Entirely } \\
\text { discoloured seeds } \\
(\%)\end{array}$ & $\begin{array}{c}\text { Seeds with discoloured } \\
\text { embryo (germ) end (\%) }\end{array}$ & $\begin{array}{c}\text { Seeds with } \\
\text { discoloured brush } \\
\text { end (\%) }\end{array}$ \\
\hline Sonalika & 15.75 & 72.25 & 2.0 & 1.25 & 1.0 \\
Siette Ceros & 28.75 & 65.50 & 12.50 & 1.50 & 0.75 \\
Pavon 76 & 27.0 & 64.25 & 5.50 & 0.00 & 1.25 \\
Indus 66 & 10.75 & 79.75 & 1.00 & 1.50 & 0.25 \\
\hline
\end{tabular}

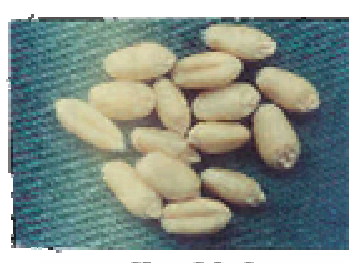

Maned Seels

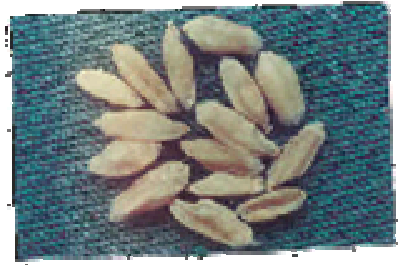

Windseds

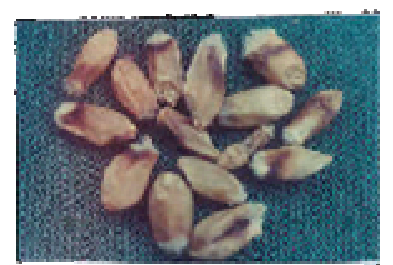

Sed with tisdonmel hot an

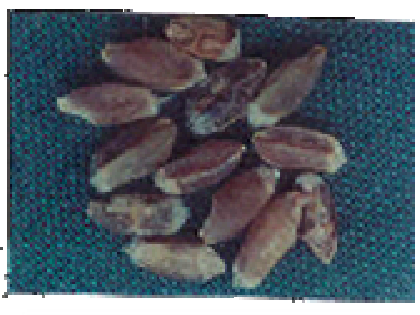

Entirely discoloured steds

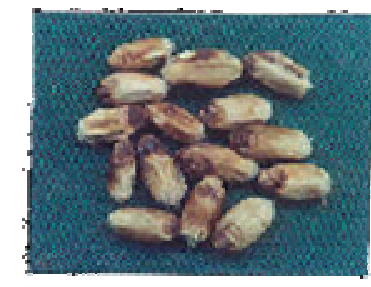

Seed with discoloured enhryo (perm end)

Figure 1. Normal and abnormal wheat seed types.

with malformed seed shapes, wrinkled seed coats, discolouration or those with fungal propagules. Four replicate samples each of 100 seeds per cultivar were examined.

\section{Isolation of fungi associated with normal and abnormal seeds}

400 seeds from both normal and abnormal samples were surfacesterilized $(1 \% \mathrm{NaOcl}$ for $5 \mathrm{~min})$ and plated on blotter at the rate of 25 seeds per $9 \mathrm{~cm}$-diameter Pyrex Petri dish. These were incubated for 7 days at $28 \pm 2^{\circ} \mathrm{C}$ under alternating cycles of $12 \mathrm{~h}$ daylight and $12 \mathrm{~h}$ darkness. Fungi observed on seeds were identified and counted and further expressed as percentage of the total number of such seeds (normal or abnormal) plated on blotter. Germinated seeds were counted and expressed as a measure of seed viability using the formula:

$\mathrm{Sv}=\mathrm{n} / \mathrm{N} \times 100$

Where Sv is \% seed viability, $\mathrm{n}$ is the number of seeds germinated from each normal or abnormal seed type and $\mathrm{N}$ is the total number of seeds (normal or abnormal type) plated on blotter.

\section{RESULTS}

Table 1 shows the incidence of normal and abnormal seeds from dry inspection of seeds. There were more abnormal than normal seeds. Figure 1 shows the nature of normal and abnormal seed types. Incidence of normal seeds was $10.7-28.7 \%$ while the different abnormal seed types was $0.75-79.7 \%$ across all cultivars. With incidence $64.2-79.7 \%$, wrinkled seed type was the most common form of abnormality. Incidence of entirely discoloured seed was 12.5 and $5.5 \%$ on Siette ceros and Pavon 76, respectively. Colouration of entirely discoloured seeds varied from brown through dark-brown to black, most of which were dented in shape (Figure 1). Incidence of seeds with discoloured embryo (germ) and brush ends was $1.2-1.5 \%$ and $0.7-1.2 \%$ (Table 1 ).

Fusarium graminearum and Helminthosporium sativum were isolated from both normal and abnormal seeds, however with a higher incidence in abnormal than normal seeds (Table 2). Alternaria tenuis (17.5\%) and Curvularia lunata (3.7\%) were also isolated additionally from entirely discoloured seeds. Incidence of $F$. graminearum was $2.2 \%$ on normal seeds while it was $10.5-78.5 \%$ on the abnormal seed types. Incidence of F. graminearum was high (78.5 and $67.5 \%$, respectively) on seeds with discoloured brush end and entirely discoloured seeds. Incidence of $H$. sativum was highest 
Table 2. Viability and mycoflora of normal and abnormal seeds of rain-fed wheat.

\begin{tabular}{|c|c|c|c|c|}
\hline Seed Type & $\begin{array}{c}\text { Germination } \\
(\%)\end{array}$ & Associated Fungi & $\begin{array}{l}\text { Incidence of } \\
\text { Fungi }^{*}(\%)\end{array}$ & $\begin{array}{c}\text { Seed Infection } \\
(\%)\end{array}$ \\
\hline Normal Seed & $88.0 \pm 0.10$ & $\begin{array}{c}\text { F.graminearum } \\
\text { H. sativum }\end{array}$ & $\begin{array}{l}2.25 \pm 0.45 \\
0.50 \pm 0.10\end{array}$ & $0.68 \%$ \\
\hline Wrinkled Seed & $\begin{array}{c}32.0 \pm 1.24 \\
5.0 \pm 4.0\end{array}$ & $\begin{array}{c}\text { F. graminearum } \\
\text { H. sativum } \\
\text { F. graminearum }\end{array}$ & $\begin{array}{c}10.50 \pm 0.74 \\
2.50 \pm 0.32 \\
67.50 \pm 0.36\end{array}$ & $3.25 \%$ \\
\hline EntirelyDiscoloured Seed & & $\begin{array}{l}\text { H. sativum } \\
\text { A. tenuis } \\
\text { C. lunata }\end{array}$ & $\begin{array}{c}30.0 \pm 1.0 \\
17.50 \pm 2.24 \\
3.75 \pm 5.20\end{array}$ & 29.68 \\
\hline $\begin{array}{l}\text { Seed with Discoloured embryo } \\
\text { (germ) end }\end{array}$ & $1.50 \pm 1.03$ & $\begin{array}{l}\text { F.graminearum } \\
\text { H. sativum }\end{array}$ & $\begin{array}{c}14.25 \pm 0.50 \\
86.0 \pm 1.42\end{array}$ & 25.06 \\
\hline Seed with Discoloured brush end & $3.75 \pm 2.0$ & $\begin{array}{c}\text { F. graminearum } \\
\text { H. sativum } \\
\end{array}$ & $\begin{array}{l}78.50 \pm 0.15 \\
10.25 \pm 2.10\end{array}$ & 22.18 \\
\hline
\end{tabular}

Values are means from four cultivars of wheat.

* \pm S. E. - Standard Error.

(86.0\%) on seed with discoloured embryo end (Table 2). Seed abnormality types that are associated with seed discolouration had a higher incidence of fungal infection of seeds (Table 2). Overall infection was highest (29.6\%) in entirely discoloured seeds. Germination of normal seeds was $88.0 \%$ and this was higher than that $(1.5-$ $32.0 \%$ ) of the abnormal seed types.

\section{DISCUSSION}

The dry inspection of seeds revealed a higher incidence of wrinkled and discoloured than normal seeds. This is due to grain weathering (Field deterioration of grains), which, according to Tyagi and Olugbemi (1980) results from fungal infection of wheat heads under humid conditions. Grain weathering manifests as discolouration, rough appearance, shriveling, loss of texture or reduced size (Tyagi and Olugbemi, 1980). The discolouration of most seeds revealed black-point symptom as described by Varshney (1990). It manifests on the pericarp as brown to dark-brown discolouration, usually around the embryo end of the seeds. However, a substantial discolouration of the brush end was observed in this study. The association of $F$. graminearum and $H$. sativum with all forms of seed abnormalities and its relatively high incidence on discoloured seeds indicates the susceptibility of the wheat crop to these fungal species, and similar to the reports of Varshney (1990).

The association of $F$. graminearum with the black-point disease may be due to severe head blight infections induced on rain-fed wheat heads in the field from which seeds were obtained. Adlakha and Joshi (1974) reported that severe infection of wheat heads cause discolouration and shriveling of the seed. Parry et al. (1995) had listed $F$. grammearum as one of the several Fusarium spp. associated with the head blight (scab) of wheat. The shrunken nature of seeds produced from scab - $(F$. graminearum) - infected heads have also been reported by Cook (1981) and Gary (1993). H. sativum is also associated with wheat seed discolouration and blackpoint (Raemakers, 1987). It was reported that $H$. sativum-induced black-point was a result of severe head infection by the fungus. The prevalence of $H$. sativum on entirely discoloured seeds underscore earlier reports by Tyagi and Olugbemi (1980). Adlakha and Joshi (1974) had also indicted $H$. sativum as causing severe discolouration of seeds. Alternania tenuis isolated from entirely discoloured seeds is also a reputed black-point pathogen (Parashar and Chohan, 1967; Prescott et al., 1986; Varshney, 1990). It becomes obvious, therefore, that the abnormalities observed on entirely discoloured seeds in this study is the result of a combined influence of these black-point pathogens alongside C. lunata. $C$. lunata is being associated with the black-point disease for the first time in this study.

The reduced viability of abnormal seeds is due to the influence of fungi. Fakir (1988) reported significant reduction in the germination of infected seeds while Rena and Gupta (1982) reported that localized discoloured areas, usually around the embryo end of seeds are often responsible for reduced germinability. Mehta (1993) also reported that seed infection by Cochliobolus sativus adversely affected seed germination, and some cause loss of seed viability when severity of infection is high. Hence, seed infection and discolouration by $\mathrm{H}$. sativum or $F$. graminearum adversely affected rain-fed wheat cultivation in South-Western Nigeria. 


\section{REFERENCES}

Adlakha KL, Joshi LM (1974). Black point of wheat. Indian Phytopath. 27: $41-44$.

Cook RJ (1981). Fusarium diseases of wheat and other small grain in North America. In: Nelson PE, Toussoun TA, Cook RJ (eds.) Fusarium Diseases and Taxonomy. Pennsylvania State University Press, University Park. 45700.

Fakir GL (1988). Report on investigation into Black-point disease of wheat in Bangladesh. Bangladesh Agricultural University, Mymensingh, Bangladesh.

Gary CB (1993). Scab (Head blight). In: Mathur SB, Cunfer MB (eds.) Seed-borne diseases and seed health testing of wheat. Danish Government Institute of Seed Pathology for Developing Countries. pp. $83-93$.

Mehta YR (1993). Spot blotch. In: Mathur SB, Cunfer MB (eds.) Seedborne diseases and seed health testing of wheat. Danish Government Institute of Seed Pathology for Developing Countries. pp. $105-112$.

Nanaiah MI, Rai PV, Rajagopal BS (1986). Aflatoxin production in wheat flour and it's effect on protein and carbohydrate content of flour. J. Food Sci. Tech. 23(1): $20-24$.

Owolade BF, Fawole B, YOK Osinkanlu (2001). Fungi associated with maize seed discolouration and abnormalities in South Western Nigeria. Afr. Crop Sci. J. 9(4): 693 - 697.

Parashar RD, Chohan JS (1967). Effect of black point, both Alternania sp. and Helminthosporium sativum on seed germination under laboratory and field conditions and on yield. J. Res. Ludhiana 4: $73-$ 75.

Parry DW, Jenkinson P, McLeod L (1995). Fusarium ear blight (scab) in small grain cereals - Rev. Plant Pathol. 44(2): $207-238$.

Prescott JM, Burnett PA, Saari EE (1986). Wheat diseases and Pests. A guide to field identification CIMMYT Mexico. p.135.

Raemakers RH (1987). Helminthosporium sativum; Disease complex on Wheat and source of resistance in Zambia. In: AR Klatt (ed.) Wheat production constraints in tropical environments. Proceeding of International Conference on Wheat Thailand, pp. 175 -186.
Rena JP, Gupta PKS (1982). Occurrence of Black point disease of wheat in West Bengal. In. Phytopathol. 35: 700-702.

Shetty HS (1993). Different types of damages in seeds caused by seedborne fungi. In: Mathur SB, Jorgensen Jons (eds.) Seed Pathology: Proceedings of CTA seminar. Copenhagen, Denmark, 1988. pp. 53 $-62$.

Tanaka T, Yamaomoto S, Hasegawa A, Acki N, Bashing JR, Sugiuro Y, Ueno $Y$ (1990). A survey of the natural occurrence of Fusarium mycotoxins, deoxynivalenol, nivalenol and Zearalenone in cereals harvested in the Netherlands. Mycopathologia 110: $19-22$.

Tenkouano, A. and P. Sereme (1996). Some implications of genotype $x$ environment interactions on sowing seed quality of sorghum. Afr. Crop Sci. J. 4(1): $11-18$.

Tyagi PD, Olugbemi LB (1980). Rain-fed wheat in Nigeria as influenced by fungal pathogens and adverse weather conditions. Samaru Miscellaneous paper 91: $1-15$.

Varshney JL (1990). Seed-borne diseases of wheat - their impact in relation to production and productivity. Int. J. Trop. Dis. 8: 173-192.

Venter VA (2000). What is seed vigour? Int. Seed Test. Ass. News Bulletin 121: $13-14$

Vijaya, KP, Karana D (1981). Deterioration of cowpea seeds in storage by Aspergillus flavus. Indian Phytopathol. 34: 222 - 223.

Wiese MV (1987). Compendium of Wheat diseases. $2^{\text {nd }}$ Ed. American Phytopathological Society. USA. p. 256.

Williams, KC, Blaney BJ (1994). Effect of the mycotoxins, nivalenol and Zearlenone in maize naturally infected with Fusarium graminearum on the performance of growing and pregnant pigs. Aust. J. Agric. Res. 45(6): $1265-1279$. 